\title{
Mediacja jako sposób rozwiązywania sporów gospodarczych o charakterze transgranicznym na przykładzie Polski i Niemiec
}

\begin{abstract}
Streszczenie: Celem niniejszego opracowania jest nakreślenie specyfiki gospodarczych sporów transgranicznych oraz zaprezentowanie mediacji jako metody ich rozwiązywania, alternatywnej wobec sądów powszechnych, dającej zwaśnionym stronom możliwość zarówno ich szybszego i mniej kosztownego zakończenia, jak i kontynuowania relacji gospodarczych oraz rozwijania dalszej współpracy pomiędzy przedsiębiorcami. W pierwszym kroku określone zostaną cechy konstytutywne mediacji oraz specyfika mediacji transgranicznej ze szczególnym uwzględnieniem aspektów interkulturowych. W tym kontekście przedstawione zostaną specyficzne kompetencje mediatora, niezbędne do skutecznego przeprowadzenia postępowania mediacyjnego w tego typu konfliktach oraz podstawy prawne zastosowania mediacji w odniesieniu do sporów pomiędzy podmiotami z Polski i Niemiec. Omówione zostaną zarówno regulacje prawa polskiego i niemieckiego dotyczące mediacji, jak i ramy i uwarunkowania instytucjonalno-prawne postępowania mediacyjnego w UE w zakresie sporów gospodarczych o charakterze transgranicznym. Ponadto analizie poddane zostaną dane empiryczne dotyczące zakresu upowszechnienia mediacji w obu krajach, stosunku polskich i niemieckich przedsiębiorców do mediacji jako metody rozwiązywania sporów gospodarczych pomiędzy podmiotami z obu krajów oraz trudności w jej zastosowaniu wynikające z różnic kulturowych.
\end{abstract}

Słowa kluczowe: mediacja, spory gospodarcze, rozwiązywanie konfliktów, transgraniczność, interkulturowość

D obrosąsiedzkie stosunki polsko-niemieckie od wielu lat w istotnej mierze współkształtowane są przez ścisłą i intensywną współpracę gospodarczą pomiędzy tymi dwoma krajami. Od czasu transformacji ustrojowej, która w Polsce miała miejsce w latach 90-tych minionego stulecia, Niemcy stały się jej najważniejszym partnerem handlowym, wyprzedzając w sposób zdecydowany inne kraje (GUS, 2015). Jednocześnie stale rośnie również znaczenie Polski dla gospodarki niemieckiej. Będąc największym rynkiem wśród tzw. nowych państw członkowskich Unii Europejskiej, Polska posiada kluczową pozycję wśród krajów Europy Środkowo-Wschodniej i jest największym partnerem handlowym Niemiec w tym rejonie. Ponadto, zajmując siódme miejsce w niemieckiej statystyce dotyczącej handlu zagranicznego w 2015 r., Polska wyprzedziła takie kraje jak Szwajcaria, Belgia czy Rosja. Podczas gdy, mimo wzmożonej konkurencji międzynarodowej, Polska postrzegana jest przez niemieckich przedsiębiorców jako miejsce wiodące pod względem atrakcyjności inwestycyjnej w Europie Środkowo-Wschodniej, również Niemcy stają się dla polskich przedsiębiorstw krajem coraz bardziej interesującym pod kątem inwestycji oraz tworzenia nowych miejsc pracy (Auswärtiges Amt der Bundesrepublik Deutschland).

Niestety nieodłączną cechę obrotu gospodarczego stanowią także spory pomiędzy biorącymi w nim udział podmiotami, których z uwagi na charakterystykę tego sektora, 
z natury rzeczy nierzadko nie sposób jest uniknąć (Walentynowicz, 2015). Ponieważ możliwość zażegnania tego rodzaju konfliktów ma zazwyczaj decydujące znaczenie dla dalszego losu współpracy transgranicznej, niezmiernie istotny w takiej sytuacji staje się sposób oraz konsekwencje przyjętej formy ich rozwiązania.

Celem niniejszego opracowania jest nakreślenie specyfiki gospodarczych sporów transgranicznych oraz zaprezentowanie mediacji jako metody ich rozwiązywania alternatywnej wobec sądów powszechnych, dającej zwaśnionym stronom możliwość zarówno ich szybszego i mniej kosztownego zakończenia, jak i kontynuowania relacji gospodarczych oraz rozwijania dalszej współpracy pomiędzy przedsiębiorcami (Walentynowicz, 2015).

W pierwszej części opracowania przybliżone zostaną pojęcie oraz konstytutywne cechy mediacji, jak również najistotniejsze korzyści płynące z zastosowania tej metody w obszarze konfliktów o charakterze gospodarczym. W następnym kroku nakreślona zostanie specyfika mediacji transgranicznej ze szczególnym uwzględnieniem jej aspektów interkulturowych, a następnie przedstawione zostaną specyficzne kompetencje mediatora, niezbędne do skutecznego przeprowadzenia postępowania mediacyjnego $\mathrm{w}$ tego typu konfliktach.

W drugiej części analizie poddane zostaną podstawy prawne zastosowania mediacji w kontekście sporów pomiędzy podmiotami z Polski i Niemiec. W tym celu w pierwszej kolejności nakreślone zostaną regulacje prawa polskiego i niemieckiego dotyczące mediacji oraz zakres jej upowszechnienia w obu krajach, a następnie omówione zostaną ramy i uwarunkowania instytucjonalno-prawne postępowania mediacyjnego w UE w zakresie sporów gospodarczych o charakterze transgranicznym.

Ostatnia część opracowania poświęcona jest stosunkowi polskich i niemieckich przedsiębiorców do mediacji jako alternatywnej metody rozwiązywania sporów gospodarczych pomiędzy podmiotami z obu krajów oraz analizie trudności w jej zastosowaniu wynikających z różnic kulturowych. W związku z intensywnością polsko-niemieckich kontaktów gospodarczych oraz złożonością i specyfiką konfliktów mających miejsce $\mathrm{w}$ tego typu relacjach przedstawione zostaną również modelowe założenia polsko-niemieckiego centrum mediacji, którego zadaniem, obok szerokiej działalności informacyjnej, będzie stworzenie sieci profesjonalnych mediatorów interkulturowych oraz propagowanie mediacji jako alternatywnej metody rozwiązywania konfliktów pomiędzy polskimi i niemieckimi podmiotami gospodarczymi.

\section{Geneza oraz cechy mediacji}

Mediacja jest jedną z najbardziej rozpowszechnionych spośród podstawowych metod rozwiązywania sporów, dających możliwość pozasądowego zakończenia konfliktu, zbiorczo określanych jako ADR (alternative dispute resolution) (Kalisz, Zienkiewicz, 2009, s. 30), które w literaturze przedmiotu definiowane są jako „zespół różnych metod i technik służących rozwiązywaniu sporu przy pomocy neutralnego i bezstronnego uczestnika [...], będących alternatywą dla rozstrzygnięcia tego sporu przez sąd państwowy" (Pieckowski, 2009, s. 258). Podstawowymi przesłankami ADR, do których 
głównych form obok mediacji zaliczane są również negocjacje, koncyliacje oraz arbitraż (Kalisz, Zienkiewicz, 2009, s. 30), jest zaniechanie konfrontacyjnego sposobu podejścia do sporu oraz koncentracja na konstruktywnym poszukiwaniu rozwiązania problemu, a za ich cechy wspólne uznaje się m.in. niski stopień sformalizowania, bezpośredni udział i współdziałanie stron w dochodzeniu do ugodowego zażegnania konfliktu oraz „prymat rzeczywistych interesów stron sporu nad dogmatyką prawa” (Morek, 2014, s. 24).

Historia mediacji sięga starożytności, a etymologiczne źródła słowa „mediacja” wywodzą się z języka greckiego medos (pośredniczący, neutralny, nieprzynależny do żadnej ze stron) oraz łacińskiego mediatio (pośrednictwo) (Bobrowicz, 2004, s. 13-14). Obecnie w literaturze przedmiotu dominuje określenie mediacji jako postępowania pozasądowego, w którym neutralna i odpowiednio do tego przygotowana osoba trzecia wypracowuje wraz ze stronami rozwiązanie powstałego pomiędzy nimi konfliktu (Weitz, Gajda-Roszczynialska, 2015, s. 36). Współczesne formy mediacji zapoczątkowane zostały w Stanach Zjednoczonych, gdzie rozwój tej metody od połowy XX w. przybrał wyjątkowo dynamiczny charakter. Pierwsze zinstytucjonalizowane formy mediacji miały miejsce $\mathrm{w}$ zakresie praw pracowniczych i związane były z utworzeniem przy Departamencie Pracy w 1947 r. instytucji pod nazwą FMCS (Federal Mediation and Conciliation Service). Za przełomowe dla rozwoju mediacji uznaje się jednak lata 60. i 70. XX w., kiedy to w oparciu o Civil Rights Act z 1964 r. powstały kolejne instytucje państwowe wykorzystujące tą metodę $\mathrm{w}$ ramach prowadzonej przez siebie działalności oraz wprowadzone zostały w życie programy promowania mediacji wśród społeczności lokalnych. Za jedną z najważniejszych przyczyn intensyfikacji rozwoju mediacji w Stanach Zjednoczonych postrzega się kryzys sądownictwa, podczas którego metoda ta stanowiła odpowiedź na potrzeby obywateli w zakresie skutecznego rozwiązywania konfliktów poza obrębem długotrwałych i kosztownych postępowań sądowych. W latach 80. XX w. działania prowadzone w ramach harwardzkiego programu mediacyjnego zaowocowały dalszym rozwojem mediacji, co uwidoczniło się m.in. w rosnącej liczbie opublikowanych w tym okresie opracowań naukowych na jej temat. Prawdziwy rozkwit mediacji miał jednak miejsce w latach 90. XX w., kiedy to w $1995 \mathrm{r}$. wydany został w USA pierwszy informator dotyczący organizacji oraz usług mediacyjnych (Dispute Resolution Directory) (Kordasiewicz, 2014, s. 35).

Obecnie instytucję mediacji wykorzystuje się w praktycznie wszystkich obszarach sądownictwa, a jej sukces w Stanach Zjednoczonych przyczynił się do implementacji programów mediacyjnych również $\mathrm{w}$ innych krajach, w tym szczególnie do rozwoju mediacji w Europie. Dzięki temu w ostatnich latach zauważyć można coraz większe zainteresowanie mediacją w Unii Europejskiej oraz rosnące poparcie ze strony Rady Europy dla jej zastosowania jako skutecznej metody rozwiązywania konfliktów (Kordasiewicz, 2014, s. 35).

W kontekście atrakcyjności mediacji jako metody alternatywnej do innych sposobów rozwiązywania sporów na szczególną uwagę zasługują liczne korzyści wynikające z jej zastosowania. Najważniejsze różnice pomiędzy mediacją a rozstrzygnięciami sądowymi lub arbitrażowymi uwidacznia poniższe zestawienie podstawowych kryteriów efektywności tych metod: 
Analiza efektywności sądu, arbitrażu i mediacji

\begin{tabular}{|l|c|c|c||}
\hline \multicolumn{1}{|c|}{ Kryteria } & Sąd & Arbitraż & Mediacja \\
\hline Koszty & wysokie & wysokie & bardzo niskie \\
\hline Czas & $\begin{array}{c}\text { bardzo długi } \\
\text { (lata) }\end{array}$ & $\begin{array}{c}\text { długi } \\
\text { (lata) }\end{array}$ & $\begin{array}{c}\text { bardzo krótki } \\
\text { (kilka dni lub tygodni) }\end{array}$ \\
\hline Kto decyduje? & sędzia & arbiter & strony \\
\hline Kto kontroluje? & prawnicy & prawnicy & brak \\
\hline $\begin{array}{l}\text { Zasady postępowania do- } \\
\text { wodowego }\end{array}$ & bardzo sformalizowane & częściowo sformalizo- & wane \\
\hline Poufność & brak & pełna & pełna \\
\hline Cel & przeszłość & przeszłość & intensywna \\
\hline Komunikacja stron & brak & niewielka & brak \\
\hline Problemy z jurysdykcją & istnieją & niekiedy istnieją & duży \\
\hline Poziom satysfakcji stron & bardzo niski & niski & sukces obydwu stron \\
\hline Rezultat & sukces/przegrana & sukces/przegrana & likwidacja stresu \\
\hline Czynnik napięcia & kontynuacja stresu & kontynuacja stresu & \\
\hline
\end{tabular}

Źródło: Pieckowski, 2012, s. 4.

Z powyższego zestawienia wynika, że z pośród przedstawionych form rozwiązywania sporów to właśnie mediacja ma wyraźną przewagę nad pozostałymi. Jest ona metodą pociagająca za sobą zdecydowanie najniższe koszty, jest najmniej czasochłonna oraz najmniej sformalizowana. Przy pełnym zaangażowaniu uczestników konfliktu zarówno w kontrolę nad przebiegiem procesu mediacyjnego, jak i w proces podejmowania decyzji dotyczącej kształtu ostatecznego porozumienia, nie tyle odnoszącego się do źródeł konfliktu powstałych w przeszłości, co ukierunkowanego na znalezienie rozsądnego rozwiązania na przyszłość, daje ona szansę na wypracowanie ugody korzystnej dla obu stron, a tym samym, w przeciwieństwie do pozostałych dwóch form, gdzie rozstrzygnięcie zawsze kończy się wygraną jednej oraz porażką drugiej strony sporu, na minimalizację stresu oraz zapewnienie stronom dużego poziomu satysfakcji.

W prawie międzynarodowym oraz legislacjach krajowych brak jest dotychczas jednolitej normatywnej definicji mediacji (Pieckowski, 2015, s. 27), lecz za jej zasadniczą istotę uważany jest nieadiudykacyjny udział w procesie rozwiązywania sporu osoby trzeciej, której głównym zadaniem jest pośredniczenie „w komunikacji stron i dochodzeniu przez nie do porozumienia, starając się poprzez racjonalną perswazję likwidować rozbieżności między stanowiskami wyjściowymi” (Kalisz, Zienkiewicz, 2009, s. 33). Osoba prowadząca mediację zachowuje postawę neutralną oraz nie przyznaje racji żadnemu z uczestników konfliktu (Kalisz, Zienkiewicz, 2009, s. 33), a jej głównym zadaniem jest „stworzenie warunków do zawarcia ugody przez osoby pozostające w sporze” dzięki możliwości zastosowania różnego rodzaju technik negocjacyjnych (Weitz, Gajda-Roszczynialska, 2015, s. 36), mających na celu zbudowanie atmosfery wzajemnego zaufania i szacunku, udrożnienia kanałów komunikacji, stymulowanie i wspieranie aktywnego słuchania opinii oraz argumentów drugiej strony (Żurawska, 2008, s. 116). Decydujący dla istoty mediacji jest brak kompetencji rozstrzygających mediatora, mającego w przeciwieństwie do arbitra jedynie możliwość przedstawienia stronom sugestii rozwiązania kompromisowego (Kalisz, Zienkiewicz, 2009, s. 33) oraz wspierania ich „w formułowa- 
niu przez nie propozycji ugodowych, lub na zgodny wniosek stron może [on] wskazać sposoby rozwiązania sporu, które nie są dla stron wiążące"

Za konstytutywne elementy postępowania mediacyjnego uznaje się tzw. ,pięć złotych zasad" mediacji, do których należą dobrowolność, poufność, bezstronność, neutralność oraz akceptowalność (Weitz, Gajda-Roszczynialska, 2015, s. 36). Obok dobrowolności, stanowiącej kwintesencję mediacji (Pieckowski, 2015, s. 144), jako jej szczególne cechy wymienia się przede wszystkim nieformalność i poufność, zapewniające optymalne środowisko do otwartej i szczerej rozmowy. Zasada bezstronności stanowi gwarancję, iż nie zachodzi żadna relacja pomiędzy mediatorem i jedną ze stron oraz, że nie opowiada się on po żadnej z nich, ani żadnej nie faworyzuje. Zasadę neutralności można natomiast ująć jako „niezwiązanie mediatora z przedmiotem sporu oraz brak interesu w jakimkolwiek szczególnym sposobie jego zakończenia, [...] [a on sam] stara się, aby jego poglądy, przekonania czy uprzedzenia [...] nie determinowały stosunku do możliwych rozwiązań" (Waszkiewicz, 2014, s. 162-163).

Dzięki powyższym zasadom postępowanie mediacyjne umożliwia stronom ,zdefiniowanie oraz wymianę poglądów, postaw, oczekiwań i interesów [oraz] [...] pozwala na znalezienie oryginalnych, nietypowych rozwiązań niedostępnych w postępowaniu sądowym lub arbitrażowym" (Pieckowski, 2015, s. 142). Sesje indywidualne z mediatorem są szansą na przełamanie bariery informacyjnej pomiędzy stronami, które nie są skłonne do ujawniania swoich interesów oraz celów w bezpośrednich negocjacjach. Osoba prowadząca mediacje umożliwia stronom analityczną oraz zobiektywizowaną ocenę własnych stanowisk i nakłania je do zdiagnozowania, określenia oraz hierarchizacji swoich interesów w poszukiwaniu rozwiązania stanowiącego wartość dodaną dla obydwu stron. W tym celu mediator rozważa ze stronami nie tylko możliwe alternatywy wobec negocjowanego rozwiązania, ale również konsekwencje nieosiągnięcia porozumienia. Głównym celem mediacji jest wypracowanie ugody, której treść będzie satysfakcjonująca dla obydwu stron sporu, a ponadto „będzie posiadać walor pełnej legalności i skuteczności i którą strony zobowiązują się dobrowolnie wykonać” (Pieckowski, 2015, s. 143).

\section{Cele i korzyści mediacji w sprawach gospodarczych}

Spory o podłożu ekonomiczno-prawnym stanowią nieodzowny element towarzyszący przedsiębiorcom w ramach prowadzonej przez nich działalności gospodarczej. Dynamiczny rozwój sektora gospodarczego sprawia, iż jest on niewątpliwie źródłem wielu sytuacji konfliktowych, co na przestrzeni ostatnich lat doprowadziło do systematycznego wzrostu liczby spraw gospodarczych kierowanych do sądów powszechnych, przy czym koszty jakie związane są z ich rozstrzyganiem stanowią poważne obciążenie dla przedsiębiorców. Obejmują one bowiem nie tylko koszty postępowań sądowych i związanej z nimi obsługi prawnej, ale także koszty zamrożonego kapitału oraz straty związane z reputacją firmy, utratą zaufania ze strony klientów i kontrahentów, czy też z pochłoniętym czasem w oczekiwaniu na rozstrzygnięcie sądowe (Hołda-Wydrzyńska, 2015, s. 157). Ponadto każdy z podmiotów gospodarczych funkcjonujących w warunkach wolnego rynku znajduje się w stałej zależ-

${ }^{1}$ Art. 1 pkt 7 ustawy z dnia 10.09.2015 r. o zmianie niektórych ustaw $w$ zwiqzku z wspieraniem polubownych metod rozwiqzywania sporów, Dz. U. 2015, poz. 1595. 
ności z innymi aktorami życia gospodarczego, w związku z czym długotrwałość procesów sądowych może pociągać za sobą daleko idące konsekwencje, prowadzące częstokroć do utraty wizerunku firmy, destabilizacji sytuacji finansowej firmy i jej otoczenia oraz mające nierzadko destruktywny wpływ na relacje biznesowe (Jakubik, 2011, s. 51).

Bezsporne jest zatem, iż przeciążenie i niewydolność wymiaru sprawiedliwości oraz związana z tym przewlekłość postępowań sądowych, z którą boryka się większość krajów UE, stanowi nie tylko istotną barierę dla sprawnego funkcjonowania poszczególnych przedsiębiorstw, ale mają także ogólnie negatywny wpływ na ogólny rozwój przedsiębiorczości. Z tego powodu głównym celem mediacji gospodarczej jest „,możliwie szybkie rozwiązanie sporu przy jak najniższych kosztach i przy maksimum dyskrecji” (Orłowski, 2015, s. 15). Mediacja może być stosowana do rozwiązywania większości sporów, również takich, które charakteryzują się dużą kompleksowością lub znaczną liczbą zaangażowanych podmiotów (Tański, 2015). Stanowiąc alternatywę dla sądów powszechnych jest ona przy tym doskonałym instrumentem, służącym do nawiązania ponownego dialogu pomiędzy zwaśnionymi stronami oraz zwiększającym szanse na osiagnięcie porozumienia, co w efekcie końcowym pozwala zarówno na skrócenie czasu postępowania, jak i na zdecydowane zmniejszenie wynikających z niego kosztów, a tym samym minimalizację strat spowodowanych zaistniałym konfliktem (Hołda-Wydrzyńska, 2015, s. 157-158).

W związku z powyższym, spośród wielu spraw w obrębie prawa cywilnego, dopuszczających zawarcie ugody, „której treść zamiast sądu, w granicach określonych prawem, mogą swobodnie kształtować skonfliktowane strony" (Hołda-Wydrzyńska, 2015, s. 161), mediacja pełni szczególną rolę w zakresie tzw. spraw gospodarczych, za które w literaturze przedmiotu uznaje się ,sprawy ze stosunków cywilnych między przedsiębiorcami [...] w zakresie prowadzonej przez nich działalności gospodarczej" (Morek, 2004, s. 16). Sprawy tego typu, zarówno w relacjach czysto wewnętrznych (krajowych), jak i w obrocie międzynarodowym, z racji swego charakteru w szczególny sposób nadają się do postępowania mediacyjnego (Weitz, Gajda-Roszczynialska, 2015, s. 52). Do konfliktów powstałych na tle stosunków pomiędzy podmiotami gospodarczymi, możliwych do rozwiązania za pomocą mediacji, należą spory, których przedmiotem jest: m.in. zapłata, niewykonanie lub nienależyte wykonanie zobowiązania, uprawnienia wspólników oraz kwestie związane z funkcjonowaniem lub rozwiązywaniem spółek, prawa konsumentów, naruszenie zasad uczciwej konkurencji i inne (Tański, 2015).

Spory o charakterze gospodarczym powstają przeważnie w warunkach stałej kooperacji pomiędzy stronami, dlatego też tak istotne staje się znalezienie odpowiedniej formy ich rozwiązania, umożliwiającej zaangażowanym $\mathrm{w}$ konflikt stronom pozostanie $\mathrm{w}$ dobrych relacjach partnerskich oraz kontynuację współpracy (Weitz, Gajda-Roszczynialska, 2015, s. 52). Należy przy tym podkreślić, że mediacja pozwala nie tylko na polubowne rozwiązywania istniejących sporów, ale nadaje się również doskonale do wypracowywania zasad wzajemnych stosunków pomiędzy zainteresowanymi stronami tak, aby zapobiec powstawaniu konfliktów w przyszłości (Tański, 2015). Ponadto dzięki niskim kosztom postępowania mediacyjnego, jego poufności oraz możliwości względnie szybkiego rozwiązania sporu, sprawne i skuteczne przeprowadzenie mediacji niejednokrotnie umożliwia nie tylko odzyskanie płynności finansowej oraz skoncentrowanie uwagi na prowadzonej działalności, ale także pozwala na zachowanie wizerunku przedsiębiorcy potrafiącego w elegancki sposób zażegnać ewentualne konflikty ze swoimi partnerami biznesowymi, klientami czy 
kontrahentami, co ma niewątpliwie bezpośrednie przełożenie na pozycję rynkową biorących udział w sporze przedsiębiorców (Hołda-Wydrzyńska, 2015, s. 161).

Skuteczność mediacji jako pozasądowego rozwiązywania sporów potwierdzają liczne badania empiryczne (Pieckowski, 2012, s. 6). Z badań przeprowadzonych przez Centrum ADR w Rzymie wynika, iż zjawisko ekonomicznej przewagi mediacji nad postępowaniami sądowymi oraz arbitrażowymi ma w krajach członkowskich UE charakter jednolity i bezsporny (ADR Center, 2010). Na podstawie wyników zawartych w niniejszym raporcie można stwierdzić, iż mediacja gospodarcza w skali UE jest średnio ok. 8 razy szybsza i 2,5 razy mniej kosztowna od postępowania sądowego oraz blisko 6 razy szybsza i ponad 5 razy mniej kosztowna niż rozstrzygnięcie w ramach postępowania arbitrażowego (Pieckowski, 2015, s. 20).

\section{Specyfika mediacji transgranicznej}

W czasach postępującej globalizacji, intensywnych procesów migracyjnych oraz wzmożonych kontaktów międzynarodowych coraz częściej mamy do czynienia z konfliktami o podłożu interkulturowym. Jak wynika z przeprowadzonych badań, szczególnie w sferze gospodarczej, w której w sposób wyjątkowo dynamiczny rośnie zarówno zakres, jak i wielopłaszczyznowość współpracy pomiędzy przedsiębiorstwami z różnych krajów, najskuteczniejszym instrumentem stosowanym do rozwiązywania konfliktów o charakterze międzynarodowym jest mediacja (Jakubik, 2011, s. 69). Mimo, że nie istnieje dotychczas uniwersalna definicja mediacji interkulturowej można uznać, iż znajduje ona swoje zastosowanie w konfliktach, w których biorące w nich udział strony charakteryzuje różne pochodzenie kulturowe (Kriegel-Schmidt, 2012, s. 121-136), mogące mieć wpływ zarówno na przyczynę, jak i na przebieg rozwiązywania sporu (Winiarska, 2014, s. 249). Dlatego też mediację interkulturową charakteryzuje większa kompleksowość, która związana jest ze szczególnym podłożem eskalacji konfliktu, wymagającym uwzględnienia aspektów kulturowych w trakcie procesu mediacyjnego (Jakubik, 2011, s. 67).

Każde indywiduum jest częścią pewnej kolektywnej tożsamości i podlega specyficznej dla danej kultury socjalizacji (Jakubik, 2011, s. 65). Do elementów cechujących kulturę można obok przedmiotów materialnych zaliczyć również wierzenia, wiedzę, sposób postrzegania oraz wzorce interpretacji rzeczywistości, doświadczenia, system wartości, organizacja życia społecznego oraz relacje przestrzenne. Kultura wytwarzana w ramach przynależności społecznej przejawia się głównie w normach zachowania, języku, wzorcach komunikacji oraz rolach i strukturach społecznych (Winiarska, 2014, s. 249). Różnice kulturowe wynikające $\mathrm{z}$ wychowania $\mathrm{w}$ odmiennych środowiskach, posiadających różne tradycje, obyczaje czy systemy hierarchii społecznej, mogą odzwierciedlać się w odmiennych przekonaniach, rozbieżnym poczuciu czasu czy istoty dumy, szacunku lub zaufania oraz różnych sposobach zachowania (Jakubik, 2011, s. 67) i mogą determinować zarówno preferowane sposoby rozwiązywania kwestii spornych, jak i mieć daleko idący wpływ na proces komunikacji pomiędzy stronami biorącymi udział w sporze (Winiarska, 2014, s. 249).

Jako trzy podstawowe elementy determinujące cechy kulturowe oraz sposób nastawienia do konfliktu, mogące mieć istotny wpływ na sytuację mediacyjna, wymienia się przede wszystkim środowisko naturalne, od którego zależy specyficzne podejście do współpracy 
i rywalizacji, historię, zawierającą zarówno dzieje i doświadczenia danych społeczności, jak i historię ich wzajemnych kontaktów i relacji oraz struktury społeczne, w skład których wchodzą przyjęte struktury rodzinne i wspólnotowe, systemy prawne i kontrolne, struktury polityczne, biurokratyczne i ekonomiczne, poziom rozwoju społeczeństwa obywatelskiego, jak również religia i/lub ideologia (Moore, Woodrow, 2010, s. 24-30).

W literaturze przedmiotu jako najważniejsze wymiary różnicujące odmienne kultury wymienia się: indywidualizm vs. kolektywizm, „dystans władzy”, unikanie vs. aprobata niepewności, męskość vs. kobiecość oraz orientację długo- vs. krótkofalową (Hofstede, 2009). W kulturach indywidualistycznych na pierwszym miejscu stawiane jest dobro jednostki, przedkładane ponad dobro grupy oraz intencjonalne dążenie do realizacji własnych celów i osiagnięcia osobistego sukcesu. Kolektywizm natomiast charakteryzuje się przedkładaniem dobra ogółu nad interesy jednostki, której tożsamość związana jest z przynależnością do danej grupy i zobowiązuje ją do przestrzegania przyjętych w niej zasad oraz zachowania wobec niej lojalności (Winiarska, 2014, s. 254). „Dystans władzy” związany jest z poziomem hierarchiczności oraz gotowością do uznania autorytetów obowiązujących $\mathrm{w}$ danej społeczności. Kolejnym istotnym wymiarem kultury jest kwestia dopuszczalnego poziomu niepewności, czyli zdolność jej przedstawicieli do podjęcia lub tolerowania ryzyka, jako oczywistego składnika otaczającej rzeczywistości. Ponadto dla tzw. „kultur męskich” charakterystyczne jest przykładanie szczególnej wagi do sukcesu materialnego, siły, umiejętności forsowania własnych interesów oraz wydajności i skuteczności. W przeciwieństwie do tego w tzw. „kulturach żeńskich” na pierwszym miejscu stoją relacje interpersonalne, skromność, solidarność, empatia oraz jakość życia niezwiązana z dobrami materialnymi. Ostatni wymiar odnosi się do różnic pomiędzy dominacją w danej społeczności postawy pragmatycznego kreowania przyszłości, w przeciwieństwie do dogmatycznej orientacji na teraźniejszość (Jakubik, 2011, s. 151-157).

Osoby pozornie podobne po względem widocznych przejawów kultury, takich jak ubiór, symbole czy sposób zachowania, które stanowią jedynie niewielki wycinek cech kulturowych, mogą różnić się w sposób znaczny w zakresie cech często nieuświadomionych, takich jak normy, przekonania, sposób myślenia i postrzegania rzeczywistości, które mają decydujące znaczenie dla kontaktów z innymi. Osoby o różnym pochodzeniu widzące świat przez pryzmat innych wzorców kulturowych, mogą inaczej interpretować docierające do nich komunikaty oraz w odmienny sposób oceniać zachowanie zarówno swoje, jak i innych. Napięcia wynikające z odmiennego sposobu rozumienia tych samych okoliczności może nie tylko stanowić źródło konfliktu, lecz również poważnie utrudniać proces jego rozwiązywania (Winiarska, 2014, s. 250).

$\mathrm{W}$ związku z powyższym podstawowym celem mediacji interkulturowej jest przełamanie barier w komunikacji pomiędzy stronami sporu, poprzez wyjaśnienie nieporozumień wynikających z różnic kulturowych oraz pomoc zarówno $\mathrm{w}$ formułowaniu własnych stanowisk, jak i rozumieniu drugiej strony, przy jednoczesnej redukcji poczucia zagrożenia związanego z innym sposobem postrzegania tych samych kwestii, wynikającym z różnego tła kulturowego skonfliktowanych osób (Jakubik, 2011, s. 69).

Dlatego też decydującym dla skuteczności postępowania mediacyjnego jest rola mediatora, który oprócz podstawowych umiejętności i znajomości technik koniecznych do wypracowania porozumienia pomiędzy stronami oraz kwalifikacji gwarantujących prawidłowy przebieg postępowania mediacyjnego (Michnowicz, 2015, s. 85), 
musi w przypadku konfliktów transgranicznych posiadać również odpowiednią wiedzę umożliwiającą mu uwzględnienie różnic pomiędzy stronami, wynikających z ich podłoża kulturowego (Jakubik, 2011, s. 118). Szczególnie istotna dla możliwości stworzenia konstruktywnej relacji pomiędzy uczestnikami sporu jest pomoc ze strony mediatora w zrozumieniu zarówno własnych, jak i obcych wzorców zachowania oraz uświadomieniu sobie roli różnic kulturowych w zaistniałym konflikcie (Jakubik, 2011, s. 67).

Istotne dla przebiegu interakcji pomiędzy stronami są zarówno zachowania werbalne, czyli dobór słownictwa lub argumentów, jak i niewerbalne, czyli gesty, mimika czy też podejście do przestrzeni i czasu (Winiarska, 2014, s. 251). Jednym z aspektów mogących rzutować na przebieg mediacji są odmienne style komunikacji charakterystyczne dla przedstawicieli danej kultury, przy czym można tu rozróżnić pomiędzy kulturą wysokiego i niskiego kontekstu (Hall, 2001). W przypadku komunikacji niskiego kontekstu mamy do czynienia $\mathrm{z}$ wyrażaniem swoich myśli, opinii czy emocji w sposób bezpośredni i wprost, zazwyczaj w formie wyrazistych komunikatów werbalnych. W komunikacji wyższego kontekstu istotną rolę odgrywa przede wszystkim ukryte przesłanie wypowiedzi oraz pozawerbalne sposoby przekazu informacji. Szczególnie ważne dla prawidłowego odczytania komunikatu jest znajomość jego kontekstu, a także znajomość obowiązujących „kodów niewerbalnych” czy też umiejętność rozpoznania subtelności i niuansów znaczeniowych. Dlatego też jedną z najważniejszych zadań mediatora interkulturowego jest stworzenie podstaw komunikacji pomiędzy stronami poprzez odpowiednią interpretację przekazywanych sobie nawzajem informacji (Winiarska, 2014, s. 252).

Dodatkową trudność w mediacji interkulturowej stanowi nierzadko bariera językowa (Winiarska, 2014, s. 253). Wiele nieporozumień interkulturowych spowodowanych jest problemami wynikającymi z różnego rodzaju niuansów znaczeniowych charakterystycznych dla danego języka (Blom, Meier, 2002, s. 89). Jednym z powodów może być fakt, że niektóre języki z natury należą do grupy języków niskiego kontekstu, zawierających liczne zwroty bezpośrednie oraz podkreślających związki przyczynowo-skutkowe, natomiast inne są z natury językami wysokiego kontekstu, ukazującymi powiązania oraz zawierającymi rozbudowane metafory (Winiarska, 2014, s. 253). Dlatego też szczególnie istotne dla skuteczności mediacji pomiędzy stronami porozumiewającymi się różnymi językami jest ich jak najlepsza znajomość przez prowadzącego postępowanie mediatora oraz jego wysoka sprawność w swobodnym formułowaniu, thumaczeniu oraz umiejętnym parafrazowaniu wypowiedzi uczestników sporu.

Wszystkie powyższe aspekty w wyraźny sposób wskazują na kluczowe znaczenie osoby mediatora oraz posiadanie przez niego odpowiednich kompetencji interkulturowych dla skuteczności postępowania mediacyjnego w sporach o charakterze międzynarodowym.

\section{Podstawy prawne mediacji w Polsce}

Mediacja ma ponad dziesięcioletnią tradycję normatywną w polskim systemie prawnym (Weitz, Gajda-Roszczynialska, 2015, s. 51). Instytucja mediacji w sprawach cywilnych została wprowadzona do polskiego prawodawstwa ustawą, która weszła 
w życie 10.12.2005 r. $^{2}$ Regulacje prawne odnoszące się do podstawowych zasad mediacji znajdują swoje odzwierciedlenie w przepisach zawartych w art. 183 Kodeksu postępowania cywilnego. Zgodnie z powyższym, mediatorem może być osoba fizyczna mająca pełną zdolność do czynności prawnych, korzystająca w pełni z praw publicznych $^{3}$, niebędąca czynnym sędzią ${ }^{4}$, przy czym ustawa nie określa niezbędnych kwalifikacji, które taka osoba musi posiadać. Mediacja jest dobrowolna ${ }^{5}$, a uzyskanie zgody obu stron na jej przeprowadzenie konieczne jest przed rozpoczęciem procesu mediacyjnego, a jego uczestnicy mogą w każdej chwili mediację przerwać lub z niej zrezygnować 6 . W odniesieniu do zasady mówiącej o poufności mediacji za kluczowe uważa się rozwiązanie ustawodawcze stwierdzające jej niejawność ${ }^{7}$, w myśl której mediator, o ile nie zostanie przez strony z tego obowiązku zwolniony, zobowiązany jest do zachowania w tajemnicy wszystkich faktów, o których dowiedział się w ramach prowadzonej przez niego mediacji oraz nie może zostać w odniesieniu do nich przesłuchany w charakterze świadka ${ }^{8}$. Również zasada bezstronności została usankcjonowana w treści przepisów k.p.c. ${ }^{9}$, dlatego też w sytuacji jakichkolwiek wątpliwości w tym zakresie każda ze stron może na każdym etapie mediacji wnieść o zmianę osoby prowadzącej postępowanie mediacyjne (Żurawska, 2008, s. 114). Waga zasady bezstronności mediatora została jeszcze raz podkreślona $\mathrm{w}$ wyniku nowelizacji zawartej $\mathrm{w}$ ustawie $\mathrm{z}$ dnia 10.09.2015 r. o zmianie niektórych ustaw z zwiqzku z wspieraniem polubownych metod rozwiqzywania sporów, w której art. $183^{3} \S 2$ został uzupełniony o zapisy, nakładające na mediatora obowiązek niezwłocznego „ujawnienia stronom okoliczności, które mogłyby wzbudzić wątpliwości co do jego bezstronności" ${ }^{\prime 10}$. Przepisy te wpisują się ponadto w zasadę akceptowalności, ujętej w treści przepisów, w myśl których to strony decyduja o wyborze mediatora ${ }^{11}$. W przepisach k.p.c. nie została natomiast ujęta zasada neutralności mediatora, lecz w literaturze przedmiotu można spotkać się z opinią, iż jest to zbyteczne, gdyż z definicji stanowi ona immanentną cechę procesu mediacyjnego (Żurawska, 2008, s. 113-114).

Niewątpliwą zachętę dla przedsiębiorców może stanowić fakt, że każda ugoda zawarta przed mediatorem może mieć walor egzekucyjny (Walentynowicz, 2015). Istotna w tym kontekście jest możliwość zatwierdzenia tejże ugody przez sąd poprzez nadanie jej klauzuli wykonalności, po tym, jak stwierdzone zostanie, czy zawarte w niej postanowienia „nie są sprzeczne z prawem, zasadami współżycia społecznego, nie zmierzają do obejścia prawa albo są niezrozumiałe lub zawierają sprzeczności” (Hołda-Wydrzyńska, 2015, s. 161). Dzięki temu w sytuacji niewywiązywania się przez jedną ze stron z wa-

${ }^{2}$ Ustawa z dnia 28.07.2005 r. o zmianie ustawy - Kodeks postępowania cywilnego oraz niektórych innych ustaw, Dz. U. Nr 172, poz. 1438.

${ }^{3}$ Art. $183^{2} \S 1$.

${ }^{4}$ Art. $183^{2} \S 2$.

${ }^{5}$ Art. $183^{1} \S 1$ k.p.c.

${ }^{6}$ Art. $183^{8} \S 3$ zd. 2 k.p.c.

${ }^{7}$ Art. $183^{4} \S 1$ k.p.c.

${ }^{8}$ Art. $259^{1}$ k.p.c.

${ }^{9}$ Art. $183^{3} \S 1$ k.p.c.

${ }^{10}$ Art. 1 pkt. 6 ustawy z dnia 10.09.2015 o zmianie niektórych ustaw w zwiqzku z wspieraniem polubownych metod rozwiqzywania sporów, Dz. U. 2015, poz. 1595.

${ }^{11}$ Art. $183^{9}$ k.p.c. 
runków wypracowanego porozumienia, może ona stać się bezzwłocznie przedmiotem egzekucji komorniczej (Walentynowicz, 2015).

\section{Podstawy prawne mediacji w Niemczech}

Mediacja w Niemczech jest unormowana w ustawie o mediacji, znanej jako „Mediationsgesetz" "12, która odnosi się do wszystkich rodzajów sporów, w tym również tych o charakterze gospodarczym. Ustawa mediacyjna składa się z 9 paragrafów i ustanawia jedynie ogólne wytyczne dotyczące mediacji. Rozpoczyna się ona od podania definicji pojęć „mediacja” i „mediator”, w celu odróżnienia postępowania mediacyjnego od innych sposobów rozstrzygania sporów. Zgodnie z ustawą ,,mediacja jest ustrukturyzowanym procesem, w którym zaangażowane strony $\mathrm{z}$ własnej woli i samodzielnie szukają sposobu polubownego rozstrzygnięcia sporu z pomocą jednego lub kilku mediatorów"13. Mediatorzy są w myśl ustawy „niezależnymi i bezstronnymi osobami bez uprawnień decyzyjnych, które pomagają spierającym się stronom w procesie mediacyjnym" ${ }^{14}$.

W tekście ustawy świadomie unika się dokładnego określenia sposobu postępowania w procesie mediacyjnym. W części dotyczącej procedury mediacyjnej mowa jest o tym, że wyboru mediatora dokonują strony sporu oraz określone są jego zadania, m.in. obowiązek czuwania nad dobrowolnością udziału, upewnienie się co do wiedzy stron na temat zasad obowiązujących w postępowaniu mediacyjnym, dbałość o poprawny przebieg postępowania, jak również prawo mediatora do zakończenia postępowania mediacyjnego w przypadku braku perspektyw na zawarcie ugody ${ }^{15}$. W kolejnych paragrafach wprowadzonych zostało kilka ograniczeń i obowiązków w zakresie prowadzenia mediacji, mających na celu zapewnienie niezależności i bezstronności mediatora. Przepisy stanowią ponadto, że mediatorzy zobowiązani są do zachowania względem swoich klientów ścisłej poufności ${ }^{16}$. Kolejne dwa paragrafy regulują sposób przygotowania oraz zakres kwalifikacji wymaganych od mediatora ${ }^{17}$, który dzięki odpowiedniemu wykształceniu oraz dalszym szkoleniom dysponuje zarówno wiedza, jak i doświadczeniem gwarantującym fachowy sposób prowadzenia mediacji (Okońska, 2015, s. 74).

Niemiecka ustawa mediacyjna propaguje polubowne rozstrzyganie sporów poprzez wprowadzenie do kodeksu postępowania cywilnego (Zivilprozessordnung - ZPO) elementów zachęcających, w których mowa jest m.in. o tym, że w przypadku wniesienia sprawy do sądu, strony muszą złożyć oświadczenie, czy podjęły wcześniej próbę rozwiązania sporu z wykorzystaniem mediacji lub innych środków poza procesowych oraz czy istnieje jakaś szczególna przesłanka do tego, aby takie rozwiązanie nie było brane pod uwagę. Sąd może oprócz tego zasugerować stronom podjęcie próby rozstrzygnięcia

${ }_{12}$ Mediations $G$ - ustawa o wspieraniu mediacji i innych trybów pozasądowego rozwiązywania sporów (Gesetz zur Förderung der Mediation und anderer Verfahren der außergerichtlichen Konfliktbeilegung) z 21.07.2012, BGB1. I s. 1577.

$13 \S 1$ Mediations $G$.

$14 \S 2$ Mediations $G$.

$15 \S 3$ Mediations $G$.

$16 \S 4$ Mediations $G$.

$17 \S 5, \S 6$ Mediations $G$. 
konfliktu w drodze mediacji lub z zastosowaniem innych środków poza procesowych. W sytuacji wyrażenia zgody przez strony, sąd może zarządzić zawieszenie postępowania. Niemiecka ustawa mediacyjna nie przewiduje natomiast przyznawania pomocy prawnej na mediację. Nie zawiera ona również regulacji dotyczącej wykonalności ugód mediacyjnych, ponieważ jej stwierdzenie w wystarczający sposób umożliwiają obowiązujące przepisy $Z P O$ (Okońska, 2015, s. 77).

W ustawie zawarte zostały także przepisy zobowiązujące rząd federalny do przedłożenia parlamentowi (Bundestag) sprawozdania z jej skutków pięć lat po wejściu ustawy w życie. Rząd federalny zobligowany jest wówczas do podjęcia decyzji, czy konieczne będą dalsze kroki legislacyjne dotyczące szkolenia oraz doskonalenia zawodowego mediatorów (Mediacja).

\section{Regulacje prawne dotyczące mediacji w UE}

Jednym z efektów rozwoju wolnego rynku w Unii Europejskiej była „eksplozja sporów" o charakterze transgranicznym. Wzrost ich liczby w połączeniu z niewydolnością i niedostosowaniem krajowych systemów prawnych skutkowało podjęciem szeregu działań zmierzających do uregulowania na płaszczyźnie unijnej systemu ich rozwiązywania. Zarówno liczne rekomendacje przyjęte przez Radę Europy w odniesieniu do spraw rodzinnych, karnych i cywilnych w latach 1998-2002, jak i polityka Unii Europejskiej, świadczą o dużym zaangażowaniu instytucji unijnych w upowszechnianie mediacji jako alternatywnego sposobu rozwiązywania sporów (Kordasiewicz, 2014, s. 49-50).

W wyniku wieloletnich badań przeprowadzonych przez Komisję Europejską pod kątem poprawy szeroko rozumianego stanu wymiaru sprawiedliwości w państwach członkowskich w dniu 21 maja 2008 przyjęta została dyrektywa Parlamentu Europejskiego i Rady 2008/52/WE $w$ sprawie niektórych aspektów mediacji $w$ sprawach cywilnych $i$ handlowych, zgodnie z którą pod pojęciem „mediacji” rozumie się ,zorganizowane postępowanie o dobrowolnym charakterze, $[\ldots]$ w którym przynajmniej dwie strony sporu próbują same osiagnąć porozumienie w celu rozwiązania ich sporu, korzystając z pomocy mediatora. Postępowanie takie może zostać zainicjowane przez strony albo może je zaproponować lub zarządzić sąd lub nakazać prawo państwa członkowskiego"18.

Celem dyrektywy jest ,ułatwienie dostępu do alternatywnych metod rozwiązywania sporów oraz promowanie polubownego rozwiązywania sporów przez zachęcanie do korzystania z mediacji oraz przez zapewnienie wyważonej relacji między mediacją a postępowaniem sądowym"19. Dyrektywa obejmuje swoim zakresem wyłącznie sprawy cywilne i handlowe o charakterze transgranicznym ${ }^{20}$. W regulacji unijnej nie określa się standardów kwalifikacji mediatorów, lecz zobowiązuje państwa członkowskie do wspierania mechanizmów kontroli jakości świadczonych usług mediacyjnych oraz nakazuje im wspieranie procesu szkolenia mediatorów w celu zagwarantowania stronom skutecznego, bezstronnego i kompetentnego prowadzenia mediacji ${ }^{21}$. Zawarte są w niej

18 Art. 3, pkt a dyrektywy Parlamentu Europejskiego i Rady 2008/52/WE z dnia 21.05.2008 r.

19 Art. 1, pkt 1 dyrektywy Parlamentu Europejskiego i Rady 2008/52/WE z dnia 21.05.2008 r.

${ }^{20}$ Art. 1, pkt 2 dyrektywy Parlamentu Europejskiego i Rady 2008/52/WE z dnia 21.05.2008 r.

${ }^{21}$ Art. 4 dyrektywy Parlamentu Europejskiego i Rady 2008/52/WE z dnia 21.05.2008 r. 
ponadto przepisy dotyczące zagwarantowania wykonalności ugody zawartej $\mathrm{w}$ drodze mediacji ${ }^{22}$, poufności postępowania mediacyjnego ${ }^{23}$ oraz wpływu zastosowania mediacji na okresy przedawnienia ${ }^{24}$.

Komisja Europejska upatruje w powyższej dyrektywie nie tylko instrument popularyzacji mediacji cywilnej jako pełnoprawnej formy rozwiązywania sporów, lecz postrzega ją również jako skuteczny środek na rozładowanie zatorów spraw procedowanych w sądach powszechnych oraz ocenia, iż dzięki szerszemu zastosowaniu mediacji możliwe będzie łagodzenie napięć pomiędzy obywatelami, a tym samym poprawienie ogólnej klimatu społecznego poprzez budowanie atmosfery ,nowej kultury prawnej w krajach członkowskich i między nimi, opartej na przyjaźni, rozsądnym dialogu i kompromisie" (Pieckowski, 2015, s. 51).

Implementacja powyższej dyrektywy w porządkach prawnych Polski i Niemiec nastapiła w ramach systemu monistycznego, w wyniku czego zawarte w niej regulacje w obu krajach „są tożsame dla mediacji krajowych i mediacji transgranicznych w obrębie UE” (Weiz, Gajda-Roszczynialska, 2015, s. 48).

\section{Stan obecny oraz perspektywy mediacji w kontekście polsko-niemieckich sporów gospodarczych}

W roku 2016 miejsce miała 25 rocznica podpisania polsko-niemieckiego Traktatu o dobrym sąsiedztwie i przyjaznej współpracy. Polska i Niemcy są od wielu lat stabilnymi partnerami gospodarczymi, a wymiana handlowa pomiędzy tymi krajami systematycznie rośnie i osiagnęła w 2015 r. rekordowe obroty. Polska jest w Niemczech liderem rankingu atrakcyjności inwestycyjnej spośród 16 krajów Europy Środkowo-Wschodniej, a działalność gospodarczą prowadzi tu ponad 6 tys. firm z niemieckim kapitałem, zatrudniających ponad 300 tys. osób. Obywatele Niemiec chętnie inwestują w Polsce głównie ze względu na bliskość geograficzną i kulturową, duży rynek wewnętrzny oraz bliskość innych ważnych rynków eksportowych, podobny system prawny z rozwiązaniami w kwestii spółek handlowych wzorowanymi na niemieckich, obecność lokalnych dostawców i partnerów, przy wciąż niższych kosztach produkcji i mniejszych wydatkach socjalnych. Jako inne zalety wymieniane są również członkostwo Polski w UE, wysokie kwalifikacje pracowników oraz jakość kształcenia akademickiego (Soszka-Ogrodnik, 2016).

Stale rosną również polskie inwestycje w Niemczech (Stasik, 2016), gdzie obecnie działa już 1700 spółek prawa handlowego z udziałem polskiego kapitału. Jako główne atuty inwestowania w Niemczech polscy przedsiębiorcy podają m.in. jakość infrastruktury, przewidywalność polityki gospodarczej, sprawne funkcjonowanie administracji publicznej oraz nastawienie instytucji podatkowych, przejrzystość systemu zamówień publicznych, dostępność wykwalifikowanych pracowników oraz elastyczność prawa pracy. Równie niezwykle ważnym aspektem pozytywnie postrzeganym przez polskich inwestorów jest uczciwość w interesach oraz dyscyplina płatnicza (Jaranowski, 2016).

\footnotetext{
${ }^{22}$ Art. 6 dyrektywy Parlamentu Europejskiego i Rady 2008/52/WE z dnia 21.05.2008 r.

${ }^{23}$ Art. 7 dyrektywy Parlamentu Europejskiego i Rady 2008/52/WE z dnia 21.05.2008 r.

${ }^{24}$ Art. 8 dyrektywy Parlamentu Europejskiego i Rady 2008/52/WE z dnia 21.05.2008 r.
} 
W kontekście rozwoju polsko-niemieckich relacji gospodarczych podkreślić należy również znaczenie wielopłaszczyznowej współpracy regionalnej i przygranicznej, której koordynacją zajmuje się w sposób systematyczny Polsko-Niemiecka Komisja Rządowa, składająca się z przedstawicieli niemieckich landów i polskich województw oraz szeregu bilateralnych gremiów specjalistycznych prowadzących działalność w obszarze poszczególnych sektorów gospodarki (Auswärtiges Amt der Bundesrepublik Deutschland).

W świetle dynamiki rozwoju polsko-niemieckich relacji handlowych i ogromnego potencjału dalszej współpracy pomiędzy tymi krajami oraz związanego z tym w naturalny sposób wzrostu sytuacji konfliktowych pomiędzy przedsiębiorcami z Polski i Niemiec niezwykle istotna, szczególnie ze względu na przewlekłość postępowań sądowych, staje się możliwość zastosowania alternatywnych metod do rozwiązywania tego typu sporów.

\section{Praktyka mediacji w Polsce i w Niemczech}

W odniesieniu do częstotliwości zastosowania mediacji w zakresie spraw gospodarczych w Polsce można na podstawie statystyk prowadzonych przez Ministerstwo Sprawiedliwości stwierdzić, iż mimo wciąż stosunkowo niskiego udziału postępowań mediacyjnych w ogólnej liczbie tego typu spraw rozpatrywanych w sądach, liczba spraw skierowanych do mediacji postanowieniem sądu sukcesywnie wzrasta, co z kolei świadczyć może o wzroście świadomości wśród polskich sędziów odnośnie możliwości rozwiązania tego typu spraw w sposób alternatywny do postępowania sądowego. Wyraźny wzrost liczby spraw kierowanych do mediacji nastąpił po roku $2010 \mathrm{w}$ wyniku działań popularyzujących mediację przeprowadzonych przez Ministerstwo Sprawiedliwości w ramach programów unijnych. Dzięki temu w stosunku do $2006 \mathrm{r}$. liczba spraw skierowanych łącznie do mediacji wzrosła w roku 2012 ponad dziewięciokrotnie, liczba złożonych protokołów mediacyjnych ponad ośmiokrotnie, a liczba postępowań umorzonych w wyniku zatwierdzenia ugody ponad czternastokrotnie. Tendencja ta utrzymała się również w ostatnich trzech latach, w wyniku czego liczba spraw skierowanych łącznie do mediacji w 2015 r. wyniosła 5744 i była ponownie niemalże 2,5 razy wyższa niż w latach poprzednich, liczba złożonych w tym czasie protokołów mediacyjnych to 1901, czyli niecałe 2 razy więcej niż w 2012 r., a liczba postępowań umorzonych $\mathrm{w}$ wyniku zatwierdzenia ugody wyniosła $640 \mathrm{i}$ była ponad 1,5 razy wyższa niż trzy lata wcześniej (Wydział Statystycznej Informacji Zarządczej).

Sędziowie kierujący sprawy na drogę procedury mediacyjnej upatrują istotne bariery dla wykorzystania mediacji do rozwiązywania sporów gospodarczych w Polsce głównie w nieufności w stosunku do oferowanej procedury, będącej konsekwencją niskiej świadomości oraz braku wiedzy stron na temat instytucji mediacji, niechęci pełnomocników do skorzystania $\mathrm{z}$ alternatywnej metody rozwiązania sporu oraz braku wykwalifikowanych mediatorów (Pieckowski, 2015, s. 67).

W Niemczech brak jest danych statystycznych odnoszących się do mediacji, lecz na podstawie zebranych na ten temat informacji można stwierdzić, że stosunkowo niewiele spraw rozpoczyna się od nawiązania kontaktu z ośrodkiem mediacyjnym, natomiast ustawowa regulacja nie spowodowała znacznego wzrostu liczby przeprowadzonych postępowań mediacyjnych. W 2010 r. ilość mediacji w Niemczech szacowana była na ok. 50 tys. rocznie, z czego 25 tys. to mediacje rodzinne (Okońska, 2015, s. 69). Stosunkowo 
niewielka liczba postępowań mediacyjnych w sprawach gospodarczych wynika w dużej mierze z faktu, iż z powodów pragmatycznych zarówno wśród niemieckich przedsiębiorców, którzy kierują się przede wszystkim rachunkiem ekonomicznym, jak i wśród sędziów, którzy dzięki temu nie muszą wydawać i uzasadniać wyroków, występuje wysoka gotowość do ugody (Żaczkiewicz-Zborska, 2016). Obok sędziów największy wpływ na upowszechnienie mediacji mają ponadto adwokaci, izby przemysłowo-handlowe oraz przede wszystkim towarzystwa ubezpieczeniowe, dla których wykorzystanie tej formy rozwiązywania sporów jest sposobem na obniżenie kosztów związanych z oferowanym przez nie ubezpieczeniem ochrony prawnej (Okońska, 2015, s. 69).

Niezależnie od powszechności mediacji na podstawie przeprowadzonych badań można stwierdzić, iż jest ona zarówno w Polsce, jak i w Niemczech zdecydowanie mniej czasochłonna oraz generuje niższe koszty niż rozstrzygnięcie sądowe lub arbitraż. W Polsce postępowanie mediacyjne w sprawach gospodarczych jest blisko 13 razy szybsze i niemalże 5 razy mniej kosztowne niż postępowanie sądowe oraz ponad 8 razy szybsze i generuje ponad 5 razy niższe koszty niż arbitraż. W Niemczech mediacja gospodarcza jest ponad 5 razy szybsza i średnio prawie 1,5 razy mniej kosztowna od postępowania sądowego oraz jest niemalże 4,5 razy mniej czasochłonna i generuje ponad 3 razy mniej kosztów niż rozstrzygnięcie arbitrażowe (Pieckowski, 2015, s. 20).

\section{Stosunek polskich i niemieckich przedsiębiorców do mediacji jako metody rozwiązywania konfliktów transgranicznych}

Mediacja interkulturowa w sprawach gospodarczych może być stosowana wszędzie tam, gdzie potencjał konfliktu wynikający z różnic kulturowych ma wpływ na relacje pomiędzy partnerami w obszarze ich działalności biznesowej. Wprowadzenie mediatora pomaga w wyjaśnieniu nieporozumień o podłożu interkulturowym oraz znalezieniu satysfakcjonującego dla obu stron konsensusu, dzięki czemu możliwe jest utrzymanie oraz dalszy rozwój współpracy pomiędzy zagranicznymi partnerami. Niestety brak jest danych statystycznych odnoszących się do częstotliwości stosowania mediacji w zakresie rozwiązywania sporów w sprawach gospodarczych o charakterze transgranicznym. Jednakże na fakt, iż zastosowanie mediacji interkulturowej znajduje swoje uzasadnienie również w przypadku polsko-niemieckich sporów o charakterze gospodarczym wskazują badania empiryczne przeprowadzone wśród polskich i niemieckich przedsiębiorców (Jakubik, 2011, s. 118). Wykazały one wiele różnic pomiędzy podejściem Polaków i Niemców w odniesieniu do różnych aspektów dotyczących relacji gospodarczych, takich jak rozwój długotrwałych relacji partnerskich $v s$. zawarcie umowy jako cel prowadzonych negocjacji, komunikacja pośrednia vs. bezpośrednia, akceptacja lub brak akceptacji niepunktualności, przywiązywanie mniejszej lub większej uwagi do szczegółów dokonywanych ustaleń biznesowych, sposoby podejmowania decyzji przez jedną lub większą liczbę osób oraz gotowość lub jej brak do podejmowania ryzyka, mogących stanowić przyczynę konfliktu (Jakubik, 2011, s. 237).

Innym wskaźnikiem wyraźne potwierdzającym zasadność zastosowania mediacji interkulturowej w konfliktach transgranicznych jest fakt, iż prawie $20 \%$ Niemców i niemalże 40\% Polaków uważa, iż w polsko-niemieckich relacjach biznesowych prawie zawsze występują konflikty o podłożu interkulturowym, natomiast ponad $17 \%$ Niem- 
ców i prawie 17\% Polaków nie wyklucza aspektów kulturowych jako powodu konfliktu w ramach tego typu współpracy. Również odnośnie czynników mających wpływ na niechęć do prowadzenia interesów z zagranicznymi partnerami lub utrudniających tego typu relacje, a wręcz mogące być powodem ich zerwania, 24\% Niemców i 45\% Polaków uznało, że mają one swoje podłoże w odmienności kulturowej pomiędzy Polską a Niemcami, a kolejne 19\% respondentów zarówno z Polski, jak i z Niemiec uznało to za prawdopodobne. Co ciekawe na podstawie powyższych danych można zauważyć, że polskich przedsiębiorców cechuje nieco większa sensybilizacja odnośnie aspektów interkulturowych w relacjach biznesowych niż ma to miejsce wśród ich niemieckich partnerów (Jakubik, 2011, s. 132).

Niestety pewien problem w zastosowaniu mediacji jako sposobu rozwiązywania tego typu konfliktów o charakterze gospodarczym leży w niskiej znajomości tej metody wśród polskich i niemieckich przedsiębiorców. Jedynie nieco ponad 8\% zapytanych o to Polaków i Niemców zna tą metodę lub mieli już z nią do czynienia, natomiast dla $41 \%$ niemieckich i ponad $37 \%$ polskich respondentów jest ona zupełnie obca. Nie zmienia to jednak faktu, że na pytanie o preferowany sposób rozwiązania sporu w przypadku konfliktu zaistniałego $\mathrm{w}$ relacjach pomiędzy polskimi i niemieckimi partnerami ponad 90\% zarówno Polaków, jak i Niemców opowiedziało się za metodami pozasądowymi, a jedynie nieco ponad 3,5\% Polaków oraz 2,5\% Niemców zdecydowałoby się na rozstrzygnięcie w drodze postępowania sądowego (Jakubik, 2011, s. 370).

Przeprowadzone badania potwierdzają również ogromną wagę aspektów interkulturowych przy rozwiązywaniu polsko-niemieckich sporów gospodarczych, o czym świadczy przekonanie o konieczności ich uwzględnienia w tego typu sprawach wyrażona przez większość Polaków (62\%) i niemalże połowę biorących udział w badaniu Niemców $(49,9 \%)$ (Jakubik, 2011, s. 371). Również przekonanie o decydującym wpływie mediatora, jako osoby mającej wiedzę na temat obu kultur, na szansę powodzenia mediacji pomiędzy polskimi i niemieckimi przedsiębiorcami, wyraziła stanowcza większość zarówno polskich (73\%), jak i niemieckich (68\%) respondentów (Jakubik, 2011, s. 372).

Powyższa analiza w sposób jednoznaczny wskazuje na to, iż zastosowanie mediacji interkulturowej w zakresie rozwiązywania polsko-niemieckich sporów gospodarczych jest nie tylko uzasadnione, ale i pożądane przez większą część współpracujących ze sobą przedsiębiorców z Polski i Niemiec.

\section{Podsumowanie}

Spośród znanych pozasądowych sposobów rozwiązywania sporów o charakterze gospodarczym to właśnie mediacja jest metodą, dającą największe szanse na osiągnięcie porozumienia i zachowanie potencjału kooperacji pomiędzy zwaśnionymi stronami. Stopień uciążliwości procesu rozwiązywania sporów ma nierzadko kluczowe znaczenie dla rozwoju przedsiębiorczości oraz sposóbu jej funkcjonowania (Hołda-Wydrzyńska, 2015, s. 157). W porównaniu do procesów sądowych, które w odróżnieniu od metod $A R D$ postrzegać można jako „cywilizowaną formę walki” o rację, mediacja zamiast roztrząsać nieporozumienia z przeszłości niesie ze sobą możliwość znalezienia rozwiązań na przyszłość, które dzięki wspólnemu pochyleniu się nad przedmiotem konfliktu 
umożliwiają zachowanie lub nierzadko wręcz poprawę relacji gospodarczych pomiędzy partnerami (Jakubik, 2011, s. 117).

Jako alternatywną metodę rozwiązywania sporów, szczególnie w kontekście sporów gospodarczych, mediację cechuje szereg ewidentnych zalet, takich jak skrócenie czasu postępowania oraz zmniejszenie jego kosztów, równość stron i możliwość wypracowania rozwiązania optymalnego dla obu uczestników konfliktu, poprzez zapewnienie im większej kontroli w zakresie formułowania ostatecznej treści ugody (Hołda-Wydrzyńska, 2015, s. 187).

Mediacja jest ponadto procedurą doskonale nadającą się do konstruktywnego uwzględniania różnic kulturowych w przypadku sytuacji konfliktowych o charakterze transgranicznym, których liczba w ostatnich latach znacznie wzrosła w związku z postępującymi procesami integracyjnymi w coraz bardziej globalizującym się świecie (Jakubik, 2011, s. 118). Szczególnie w odniesieniu do tego typu sporów daje ona możliwość uwzględnienia aspektów interkulturowych, co nierzadko ma decydujące znaczenie dla znalezienia źródła konfliktu oraz skuteczności prowadzonego postępowania mediacyjnego. Również w przypadku polsko-niemieckich relacji gospodarczych różnice kulturowe mogą mieć istotny wpływ na sposób funkcjonowania współpracy pomiędzy partnerami z obu krajów utrudniając je oraz zmniejszając tym samym ich ekonomiczną efektywność. W sytuacji sporu o podłożu interkulturowym pomoc mediatora posiadającego odpowiednie kompetencje, takie jak znajomość historii obu krajów i wynikających z niej wzorców kulturowych charakterystycznych dla mieszkańców danego kraju oraz umiejętność swobodnego porozumiewania się w obu językach, pozwala mu na rozpoznanie powodów zaistniałego nieporozumienia i na udrożnienie przepływu komunikacji pomiędzy stronami. Dzięki temu jest on w stanie w sposób skuteczny wspomagać proces dochodzenia do porozumienia oraz w sposób pozytywny wpłynąć na dalszy rozwój działalności gospodarczej pomiędzy zagranicznymi partnerami.

Niestety jednym z głównych powodów wciąż niedostatecznego zastosowania mediacji w polsko-niemieckich sporach gospodarczych jest brak znajomości tej metody oraz korzyści z niej płynących przez przedsiębiorców zarówno w Polsce jak i w Niemczech. Innym powodem takiego stanu rzeczy jest znikoma liczba mediatorów interkulturowych posiadających odpowiednie kompetencje konieczne do prowadzenia postępowania mediacyjnego w polsko-niemieckich sporach gospodarczych. Dlatego tak istotna jest intensyfikacja działań zmierzających do upowszechnienia mediacji jako skutecznej metody pozasądowego rozwiązywania sporów oraz regulowania konfliktów w sprawach cywilnych zwłaszcza w zakresie konfliktów transgranicznych o charakterze biznesowym. Ponadto w związku z powyższym konieczne staje się również zwiększenie nacisku na tworzenie ośrodków mediacji ukierunkowanych nie tylko na rozwiązywanie konfliktów krajowych, ale też prowadzących działalność w zakresie popularyzacji mediacji jako alternatywnej do postępowań sądowych metody rozwiązywania sporów o charakterze międzynarodowym, prowadzących badania naukowe dotyczące interkulturowych aspektów mających wpływ na poziom jej skuteczności oraz, co ważne, szkolących i certyfikujących mediatorów w zakresie umiejętności niezbędnych do prowadzenia tego typu postępowań.

Do przedsięwzięć tego typu, na które warto zwrócić uwagę w kontekście zapotrzebowania na tego typu instytucje, zaliczyć można projekt utworzenia Polsko-Niemieckiego Centrum Mediacji w Collegium Polonicum w Słubicach. Ten położony na granicy polsko-nie- 
mieckiej wspólny ośrodek akademicki Uniwersytetu im. Adama Mickiewicza w Poznaniu oraz Uniwersytetu Europejskiego Viadrina we Frankfurcie nad Odrą posiada odpowiedni potencjał naukowy oraz długoletnie doświadczenie w ramach współpracy polsko-niemieckiej oraz dysponuje doskonałą infrastruktura, konieczną do realizacji tego typu celów.

Dlatego też w świetle aktualnych zmian ustawodawczych oraz działań Ministerstwa Sprawiedliwości zmierzających do upowszechnienia mediacji, opracowano koncepcję utworzenia pod auspicjami Polsko-Niemieckiego Instytutu Badawczego w Collegium Polonicum ośrodka, którego główny zakres działalności obejmować ma prowadzenie i wspieranie interdyscyplinarnych projektów badawczych dotyczących metod ARD w sporach transgranicznych ze szczególnym uwzględnieniem mediacji o charakterze interkulturowym, inicjowanie i intensyfikowanie współpracy międzynarodowej oraz ożywienie dyskursu naukowego dotyczącego zastosowania metod $A R D$ w zakresie rozwiązywania konfliktów dwunarodowościowych. Interdyscyplinarne podejście do zagadnienia mediacji interkulturowej, które obok kwestii prawnych przewidują uwzględnienie również aspektów kulturoznawczych, lingwistycznych, psychologicznych oraz ekonomicznych, gwarantuje innowacyjność przyjętych założeń badawczych w zakresie podjętej problematyki. Innym zadaniem w ramach niniejszego przedsięwzięcia będzie szeroko zakrojone propagowanie metod pozasądowego rozwiązywania sporów poprzez organizacje wykładów, szkoleń, konferencji i sympozjów oraz wydawanie publikacji w zakresie tematyki związanej z metodami $A R D$. Ponadto planowane jest również powstanie punktu informacyjnego oraz stworzenie internetowej platformy wymiany wiedzy i doświadczeń w zakresie mediacji interkulturowej, która w przyszłości umożliwi prowadzenie krajowych oraz transgranicznych postępowań mediacyjnych za pomocą internetu (ODR - Online Dispute Resolution).

Dzięki tego typu inicjatywom mediacja ma w przyszłości szansę stać się popularną i niezwykle skuteczną formą rozwiązywania konfliktów pomiędzy polskimi i niemieckimi przedsiębiorcami oraz przyczynić się do harmonizacji oraz rozwoju współpracy gospodarczej pomiędzy tymi dwoma krajami.

\section{Bibliografia}

ADR Center (2010), The Cost of Non ADR - Surveying and Showing the Actual Costs of IntraCommunity Commercial Litigation, http://www.adrcenterinternational.com/wp-content/uploads/2016/04/Survey-Data-Report.pdf, 16.02.2017.

Auswärtiges Amt der Bundesrepublik Deutschland, Polsko-niemieckiestosunkigospodarcze, http://www.polen.diplo.de/Vertretung/polen/pl/09-wirtschaft-verkehr/03-dt-poln-wirtschaftsbeziehungen/0dt-poln-wirtschaftsbeziehungen.html, 16.02.2017.

Blom H., Meier H. (2002), Interkulturelles Management, Nwb Verlag, Herne-Berlin.

Bobrowicz M. (2004), Mediacje gospodarcze, Wydawnictwo C.H. Beck, Warszawa.

Dyrektywa Parlamentu Europejskiego i Rady 2008/52/WE z dnia 21.05.2008 r.

GUS, Rocznik statystyczny handlu zagranicznego 2015, http://stat.gov.pl/obszary tematyczne/rocznikistatystyczne/roczniki-statystyczne/rocznik-statystyczny-handlu-zagranicznego-2015,9,9.html, 16.02.2017.

Hall E. (2001), Poza kultura, Wydawnictwo Naukowe PWN, Warszawa.

Hofstede G. (2009), Kultury i organizacje: zaprogramowanie umystu, Polskie Wydawnictwo Ekonomiczne, Warszawa. 
Hołda-Wydrzyńska A. (2015), Mediacja w sprawach gospodarczych, w: Mediacja w sprawach gospodarczych. Praktyka - teoria - perspektywy, red. A. Torbus, Ministerstwo Gospodarki, Warszawa, s. 157-187.

Jakubik P. (2011), Interkulturelle Mediation in der Wirtschaft als alternative Lösungsform der Konflikte in der deutsch-polnischen Zusammenarbeit, ibidem, Stuttgart.

Kalisz A., Zienkiewicz A. (2009), Mediacja sqdowa i pozasqdowa, Wolters Kluwer Polska SA, Warszawa.

Jaranowski M. (2016), Polacy inwestuja w Niemczech. „Atrakcyjny kraj”, „Deutsche Welle”, http:// www.dw.com/pl/polacy-inwestuj\%C4\%85-w-niemczech-atrakcyjny-kraj/a-19252822, 16.02.2017.

Kordasiewicz S. (2014), Historyczna i międzynarodowa perspektywa mediacji, w: E. Gmurzyńska, R. Morek, Mediacje. Teoria i praktyka, Wolters Kluwer Polska SA, Warszawa, s. 35-51.

Kriegel-Schmidt K. (2012), Interkulturelle Mediation. Plädoyer für ein Perspektiven-reflexives Modell, LIT Verlag, Belin-Münster-Wien-Zürich-London.

Mediacja w państwach członkowskich - Niemcy, European-Justice, https://e-justice.europa.eu/content_ mediation_in_member_states-64-de-pl.do?member=1, 16.02.2017.

Mediations $G$ - ustawa o wspieraniu mediacji i innych trybów pozasądowego rozwiązywania sporów (Gesetz zur Förderung der Mediation und anderer Verfahren der außergerichtlichen Konfliktbeilegung) z 21.07.2012, BGB1. I, s. 1577.

Michnowicz M. (2015), Wymagania formalno-prawne stawiane mediatorom $w$ sprawach gospodarczych, w: Mediacje gospodarcze, red. A. Binsztok, MARINA, Wrocław, s. 84-86.

Moore C. W., Woodrow P. J. (2010), Handbook of Global and Multicultural Negotiation, Jossey-Bass, San Francisco.

Morek R. (2004), ADR - w sprawach gospodarczych, C.H. Beck, Warszawa.

Morek R. (2014), Wprowadzenie, w: Mediacje teoria i praktyka, red. E. Gmurzyńska, R. Morek, Wolters Kluwer Polska SA, Warszawa, s. 17-31.

Okońska A. (2015), Mediacja - Austria, Niemcy, Szwajcaria, w: Mediacja w sprawach gospodarczych. Praktyka - teoria - perspektywy, red. A. Torbus, Ministerstwo Gospodarki, Warszawa, s. $59-86$.

Orłowski W. (2015), Cel mediacji gospodarczych i korzyści z nich płynqce, w: Mediacje gospodarcze, red. A. Binsztok, MARINA, Wrocław, s. 15-19.

Pieckowski S. (2009), Arbitraż i mediacja w sprawach cywilnych, w: Mediacja, red. L. Mazowiecka, Wolters Kluwer Polska SA, Warszawa, s. 257-268.

Pieckowski S. (2012), Mediacja w sprawach gospodarczych, Ministerstwo Sprawiedliwości, Warszawa.

Pieckowski S. (2015), Mediacja gospodarcza, Difin, Warszawa.

Soszka-Ogrodnik K. (2016), Niemieccy inwestorzy o Polsce: Polityka minusem, „Deutsche Welle”, http://www.dw.com/pl/niemieccy-inwestorzy-o-polsce-polityka-minusem/a-19282901, 16.02.2017.

Stasik E. (2016), Rekordowe obroty w polsko-niemieckim handlu. „Znakomity wynik”, „Deutsche Welle", http://www.dw.com/pl/rekordowe-obroty-w-polsko-niemieckim-handlu-znakomitywynik/a-19179641, 16.02.2017.

Tański M. (2015), Mediacja w sprawach gospodarczych. Praktyczny przewodnik dla mediatorów, Lublin, http://caim.gov.pl/images/user_media/40/O\%20mediacji/Praktyczny $\% 20$ poradnik $\% 20$ dla\%20mediator\%C3\%B3w_Maciej\%20Tanski.pdf, 18.02.2016.

Ustawa z dnia 28.07.2005 r. o zmianie ustawy - Kodeks postępowania cywilnego oraz niektórych innych ustaw, Dz. U. Nr 172, poz. 1438.

Ustawa z dnia 10.09.2015 r. o zmianie niektórych ustaw z zwiqzku z wspieraniem polubownych metod rozwiazywania sporów, Dz. U. 2015, poz. 1595. 
Walentynowicz J. (2015), Mediacja dla przedsiębiorcy, czyli o roli mediacji w sprawach gospodarczych, http://kancelaria-ociepa.pl/pl/aktualnosci/29/mediacja-dla-przedsiebiorcy-cy li-o-rolimediacji-w-sprawach-gospodarczych, 16.02.2017.

Waszkiewicz P. (2014), Zasady mediacji, w: E. Gmurzyńska, R. Morek, Mediacje. Teoria i praktyka, Wolters Kluwer Polska SA, Warszawa, s. 157-171.

Weitz K., Gajda-Roszczynialska K. (2015), Alternatywne metody rozwiqzywania sporów ze szczególnym uwzględnieniem mediacji, w: Mediacja w sprawach gospodarczych. Praktyka - teoria - perspektywy, red. A. Torbus, Ministerstwo Gospodarki, Warszawa, s. 11-57.

Winiarska A. (2014), Kwestie kulturowe w mediacji, w: Mediacje teoria i praktyka, red. E. Gmurzyńska, R. Morek, Wolters Kluwer Polska SA, Warszawa, s. 249-269.

Wydział Statystycznej Informacji Zarządczej Departament Strategii i Funduszy Europejskich Ministerstwo Sprawiedliwości (2016a), Postępowanie mediacyjne $w$ sadach okręowych $w$ latach 2006-2015 oraz 1 pótroczu 2016 roku, https://isws.ms.gov.pl/pl/baza-statystyczna/publikacje/ download,2779,18.html, 16.02.2017.

Wydział Statystycznej Informacji Zarządczej Departament Strategii i Funduszy Europejskich Ministerstwo Sprawiedliwości (2016b), Postępowanie mediacyjne $w$ sqdach rejonowych $w$ latach 2006-2015 oraz 1 pótroczu 2016 roku, https://isws.ms.gov.pl/pl/baza-statystyczna/publikacje/ download,2779,17.html, 16.02.2017.

Żaczkiewicz-Zborska K. (2016), W Niemczech więcej ugód niż mediacji, http://www.mediacje.lex.pl/ czytaj/-/artykul/w-niemczech-wiecej-ugod-niz-mediacji, 6.02.2017.

Żurawska M. (2008), Mediacja jako nowa metoda rozwiazywania sporu z zakresu prawa pracy, w: Sady polubowne i mediacja, red. J. Olszewski, C.H. Beck, Warszawa, s. 101-127.

\section{Mediation as a way of solving cross-border economic disputes using Poland and Germany as an example}

\section{Summary}

This paper aims to outline the specificities of cross-border economic disputes and to present mediation as a means of solving them as an alternative to common courts, giving the parties the opportunity to settle their dispute faster and cheaper. Mediation also allows the involved parties to continue their economic relation and further develop their co-operation. In a first step the constitutive characteristics of mediation are determined and the specificity of cross-border mediation with particular emphasis on intercultural aspects is explained. In this context, the paper presents specific mediator competences necessary for effective mediation proceedings. Furthermore the legal basis for applying mediation to disputes between Polish and German entities will be described followed by the discussion of applicable regulation in both countries as well as the institutional and legal framework for mediation proceedings in the EU on cross-border economic disputes. In addition, empirical data on the scope of dissemination of mediation in both countries, the attitude of Polish and German entrepreneurs towards mediation and the difficulties of applying it due to cultural differences will be analyzed. The conclusions of the above analysis will be presented in the final section of the paper, which will provide a model of the Polish-German mediation center which aims, besides broad information activities, to create a network of professional intercultural mediators and to promote mediation as an alternative method of conflict resolution between Polish and German business entities.

Key words: mediation, economic dispute, conflict resolution, cross-border, intercultural 